\title{
Characteristics of the Spread of Apple Proliferation by Its Vector Cacopsylla picta
}

\author{
Barbara Jarausch, Nora Schwind, Annette Fuchs, and Wolfgang Jarausch
}

RLP AgroScience GmbH, AlPlanta-Institute for Plant Research, Breitenweg 71, D-67435 Neustadt, Germany. Accepted for publication 16 July 2011.

\begin{abstract}
Jarausch, B., Schwind, N., Fuchs, A., and Jarausch, W. 2011. Characteristics of the spread of apple proliferation by its vector Cacopsylla picta. Phytopathology 101:1471-1480.

The distribution and natural phytoplasma infection of Cacopsylla picta were investigated during a long-term field survey between 2002 and 2009 in commercial and abandoned apple proliferation-infected orchards throughout Germany, northern Switzerland, and eastern France. Comparable population dynamics were described for the different sites whereas considerable variations in the absolute population densities were observed among the years. Individual polymerase chain reaction (PCR) testing revealed, for each year, a rather stable natural infection rate with 'Candidatus Phytoplasma mali' of $\approx 10 \%$ for overwintered adults of $C$. picta. Both genders were equally highly infected although more females

infection rate of overwintered C. picta. No influence of agricultural practices was seen. However, a relationship between the incidence of the disease and the vector population density became evident on a regional scale. Successful transmission of ' $\mathrm{Ca}$. P. mali' occurred each year with overwintered individuals as well as with new adults. The transmission efficiency varied among the years within 8 to $45 \%$ for overwintered adults and 2 to $20 \%$ for individuals of the new generation. The load of single $C$. picta with ' $\mathrm{Ca}$. P. mali' was determined by quantitative realtime PCR. High phytoplasma titers were measured in overwintered adults already at their first appearance in the orchards after remigration from their overwintering hosts. Thus, the data indicate the transmission of the disease on a regional scale by remigrant adults of $C$. picta and at a local scale within the same season by emigrant adults which developed on infected plants.
\end{abstract} were caught. The overall male/female ratio was $1: 1.5$. No direct correlation was found between the infection status of the orchard and the

Apple proliferation (AP) is one of the economically most important phytoplasma diseases in Europe which seriously impairs fruit size and quality, yield, and vigor of apple trees, rendering them unmarketable and thus causing a major economic loss (21). Typical symptoms are enlarged stipules and witches' brooms in late summer or autumn, which allow a reliable identification of infected plants (36). AP was first reported in northern Italy (34) and has been detected since then in all European countries where apple is grown commercially. The highest incidences of AP are found in temperate climatic zones of Europe (21). Thus far, the geographic distribution of AP has been restricted to Europe and neighboring regions and it is not known whether this restriction is due to a missing vector or unsuitable temperatures northward or southward from this zone (15). However, only recently, its presence has been reported from outside Europe in the Asian part of Turkey (4), indicating the spread of this disease toward thus-farunaffected areas. The causative agent of AP is 'Candidatus Phytoplasma mali' which, together with other economically important phytoplasmas on fruit trees, belongs to the phytoplasma $16 \mathrm{Sr}$ group X (38). The cell-wall-less and thus-far-uncultured phytoplasmas colonize the phloem tissue of their plant host as well as the body of their insect hosts. They are spread through grafting of infected plant material or they are naturally transmitted by phloem-feeding insects $(25,44)$.

Psyllid species belonging to the taxon Cacopsylla Ossiannilsson 1970 (Hemiptera: Psyllidae) are considered to be the main vectors for European fruit tree phytoplasmas (15). Two Cacopsylla spp.

Corresponding author: B. Jarausch

E-mail address: Barbara.Jarausch@agroscience.rlp.de

doi:10.1094/PHYTO-01-11-0012

(C) 2011 The American Phytopathological Society
Additional keywords: epidemiology, gender balance. are recognized vectors of ' $\mathrm{Ca}$. P. mali': Cacopsylla picta (Förster) (synonym $C$. costalis) is the vector for ' $C a$. P. mali' in northeastern Italy (11) and in Germany (17) while C. melanoneura (Förster) was identified as main vector of this disease in northwestern Italy $(41,42)$, even though the leafhopper Fieberiella florii (Stål) has also been reported as a vector in this region (39). In contrast to northwestern Italy, the German population of $C$. melanoneura is not able to transmit ' $\mathrm{Ca}$. P. mali' (27) and, thus, $C$. picta is regarded as the only vector. The single AP-transmission event with $F$. florii reported by Krczal et al. (20) could never be repeated since (G. Krczal, personal communication). $C$. picta has a palaearctic distribution and is monophagous on Malus spp. (22). The psyllid completes one generation per year and overwinters as an adult on conifers $(8,30)$. At the end of winter (March or April), C. picta remigrants move from their overwintering sites to their main host apple for oviposition. Larval development (L1 to L5) takes 4 to 5 weeks; the newly hatched imagines (emigrants) remain in the orchards for $\approx 2$ weeks before they leave the orchards in June or July to migrate to their overwintering sites $(12,26,30)$. As far as is known, phytoplasmas are transmitted by leafhoppers (44) and psyllids $(7,43)$ in a persistent manner. This can also be supposed for the transmission of ' $C a$. P. mali' through $C$. picta because first remigrants of $C$. picta collected in apple orchards in early spring were shown to be highly infectious $(5,16,17)$. In southwest Germany, $\approx 10 \%$ of overwintering $C$. picta were naturally infected with the pathogen and both generations of $C$. picta were able to transmit the pathogen under experimental conditions $(16,17)$.

Despite some particular reports $(5,9,10,14,26)$ on AP incidence and the presence of its vector $C$. picta, all-encompassing information about the epidemiology of this important disease is still missing. Hence, the objective of this study was to collect precise and repetitive data over a period of years in order to provide a 
complete description of the relationship between the spread of this disease and the presence, life cycle, natural infectivity, and transmission capacity of its main vector in Germany and adjacent regions, $C$. picta. The quantification by ' $\mathrm{Ca}$. P. mali'-specific realtime polymerase chain reaction (PCR) (18) and defined experimental transmission trials (16) were applied to assess the infectivity of individuals of $C$. picta.

\section{MATERIALS AND METHODS}

Collection of insect and plant material. Insect collections were undertaken in selected cultivated and uncultivated apple orchards (Malus $\times$ domestica) in different apple-growing regions of Germany, eastern France (Alsace), and northern Switzerland (Table 1). Overall, we investigated 52 different sites, including 31 commercial apple orchards managed according to the principles of integrated production (IP) (3), 6 commercial apple orchards managed according to the rules of organic production (2), and 15 untreated, abandoned or scattered orchards. The infection by ' $\mathrm{Ca}$. P. mali' at the sampling sites was estimated visually by advisers and plant health inspectors by recording typical symptoms (witches' brooms and enlarged stipules) for those years with important psyllid captures (Table 1). Wherever possible, visual diagnosis was confirmed by PCR tests for detection of ' $\mathrm{Ca}$. P. mali'. Because scattered sites rarely show visual symptoms but constitute important reservoirs for $C$. picta, a random sample of trees was analyzed by PCR for the presence of ' $\mathrm{Ca}$. P. mali'.

All insect collections were done using the beating tray method according to Müther and Vogt (31). The collected insects from all regions were counted, separated in vials, and frozen at $-20^{\circ} \mathrm{C}$ for

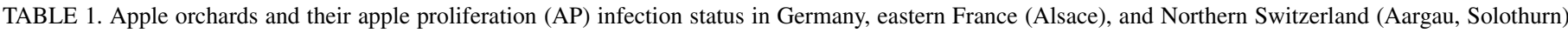
in which psyllids have been captured during 2002 to $2008^{a}$

\begin{tabular}{|c|c|c|c|c|c|c|c|}
\hline $\begin{array}{l}\text { Year of psyllid } \\
\text { captures }\end{array}$ & Region & $\begin{array}{l}\text { Site } \\
\text { code }\end{array}$ & $\begin{array}{l}\text { Orchard } \\
\text { type }\end{array}$ & $\begin{array}{c}\text { Year of } \\
\text { monitoring data }\end{array}$ & $\begin{array}{l}\text { AP infection (\%) } \\
\text { (visual diagnosis) }\end{array}$ & $\begin{array}{c}\text { PCR } \\
\left(_{(\text {positive/total })^{b}}\right.\end{array}$ & $\begin{array}{c}\text { AP infection class in } \\
\text { Table } 3(\%)\end{array}$ \\
\hline 2003-2005 & Schleswig-Holstein & SH1 & Organic & 2005 & $<1$ & nt & $<1$ \\
\hline $2003-2005$ & Schleswig-Holstein & $\mathrm{SH} 2$ & IP & 2005 & $<1$ & nt & na \\
\hline $2002-2005$ & Rheinland & AW1 & Organic & 2005 & 5 & nt & $1-5$ \\
\hline $2002-2003$ & Rheinhessen & OP1 & IP & 2003 & 11 & nt & $10-20$ \\
\hline 2002-2003 & Rheinhessen & OP2 & Organic & 2003 & 5 & nt & $1-5$ \\
\hline $2002-2005$ & Rheinhessen & OP3 & IP & 2003 & 5 & nt & $1-5$ \\
\hline 2003-2004 & Rheinhessen & OP4 & IP & 2003 & 5 & nt & $1-5$ \\
\hline 2003-2005 & Rheinhessen & OP5 & IP & 2004 & 12 & nt & $10-20$ \\
\hline 2003-2004 & Vorderpfalz & Biol & Organic & 2003 & 5 & $3 / 3$ & $1-5$ \\
\hline 2003 & Vorderpfalz & $\mathrm{Bio} 2$ & Organic & 2003 & 5 & $\mathrm{nt}$ & $1-5$ \\
\hline 2002-2006 & Vorderpfalz & HA1 & Scattered & 2001 & nt & $14 / 16(88)$ & $>75$ \\
\hline 2005 & Vorderpfalz & Klohr & Scattered & 2005 & 25 & $\mathrm{nt}$ & $25-50$ \\
\hline 2007-2008 & Vorderpfalz & MeStr & Scattered & 2010 & 43 & $3 / 3$ & $25-50$ \\
\hline 2002 & Vorderpfalz & $\mathrm{Mu}$ & Scattered & 2001 & 65 & $13 / 14$ & $50-75$ \\
\hline 2007 & Vorderpfalz & NE1 & IP & 2007 & 10 & $14 / 20$ & $10-20$ \\
\hline $2002-2005$ & Vorderpfalz & NW1 & IP & 2005 & 59 & $11 / 12$ & $>50$ \\
\hline 2006-2008 & Vorderpfalz & NW1a & IP & 2008 & 75 & $26 / 26$ & $>75$ \\
\hline 2006-2008 & Vorderpfalz & NW1b & IP & 2008 & 5 & $12 / 19$ & $1-5$ \\
\hline 2002-2005 & Vorderpfalz & NW2 & IP & 2005 & 1 & $2 / 2$ & $1-5$ \\
\hline 2003-2008 & Vorderpfalz & NW5 & IP & 2006 & 16 & $81 / 107$ & $10-20$ \\
\hline 2003-2005 & Vorderpfalz & NW6 & IP & 2005 & 3 & $39 / 40$ & $1-5$ \\
\hline 2004 & Vorderpfalz & NW7 & IP & 2003 & 5 & $2 / 2$ & $1-5$ \\
\hline 2003 & Vorderpfalz & NW8 & IP & 2003 & 5 & $2 / 2$ & $1-5$ \\
\hline 2002-2004 & Vorderpfalz & WaS1 & Scattered & 2002 & 40 & $2 / 5$ & $25-50$ \\
\hline 2002 & Vorderpfalz & WaS3 & Scattered & 2002 & 25 & $1 / 1$ & $25-50$ \\
\hline $2002-2003$ & Vorderpfalz & WaS4 & Scattered & 2002 & 75 & $1 / 1$ & $50-75$ \\
\hline $2002-2003$ & Vorderpfalz & WaS5 & Scattered & 2002 & 75 & $4 / 4$ & $50-75$ \\
\hline 2002 & Vorderpfalz & WaS6 & Scattered & 2002 & 50 & $2 / 2$ & $50-75$ \\
\hline $2002-2003$ & Vorderpfalz & WaS7 & Scattered & 2002 & 66 & $2 / 2$ & $50-75$ \\
\hline 2005-2007 & Südpfalz & Inter1 & IP & 2005 & 10 & $96 / 100$ & $10-20$ \\
\hline 2005-2007 & Südpfalz & Inter2 & IP & 2005 & 3 & $41 / 46$ & $1-5$ \\
\hline 2005-2007 & Südpfalz & Inter3 & IP & 2005 & 0 & nt & $<1$ \\
\hline 2006-2007 & Südpfalz & Inter3/H & Scattered & 2006 & 40 & $2 / 5$ & $25-50$ \\
\hline 2005-2007 & Südpfalz & Inter4 & IP & 2005 & 17 & $144 / 152$ & $10-20$ \\
\hline $2002-2007$ & Nordbaden & KA1 & IP & 2006 & 24 & $13 / 13$ & $20-30$ \\
\hline 2002-2008 & Nordbaden & KA2 & IP & 2006 & 5 & nt & $1-5$ \\
\hline $2002-2003$ & Nordbaden & KA3 & Scattered & 2003 & 50 & nt & $25-50$ \\
\hline 2003 & Nordbaden & KA4 & Scattered & 2003 & 50 & nt & $25-50$ \\
\hline 2003-2005 & Mittelbaden & OG1 & IP & 2005 & 11 & $5 / 5$ & $10-20$ \\
\hline 2005 & Mittelbaden & OG2 & IP & 2005 & 2 & $\mathrm{nt}$ & $1-5$ \\
\hline 2005-2006 & Südbaden & $\mathrm{FR}$ & IP & 2005 & 12 & nt & $10-20$ \\
\hline $2003-2005$ & Weinsberg & LPPS & IP & 2005 & 24 & nt & $20-30$ \\
\hline 2003-2006 & Bodensee & MKD1 & IP & nt & nt & nt & na \\
\hline 2003-2004 & Bodensee & MKD2 & IP & nt & nt & nt & na \\
\hline 2003-2004 & Bodensee & MKD3 & Organic & nt & nt & nt & na \\
\hline 2003-2006 & Bodensee & MKD4 & IP & 2005 & 5 & nt & $1-5$ \\
\hline 2004-2006 & Bodensee & MKD5 & Scattered & 2005 & 25 & $\mathrm{nt}$ & $25-50$ \\
\hline 2005-2007 & Alsace & Ver1 & IP & 2006 & 20 & $10 / 10$ & $20-30$ \\
\hline $2005-2007$ & Alsace & Ver2 & Scattered & 2006 & 25 & $12 / 12$ & $25-50$ \\
\hline $2005-2007$ & Alsace & Ver3 & IP & 2006 & 50 & $14 / 14$ & $30-50$ \\
\hline 2005-2007 & Aargau & $\mathrm{CH} 1$ & IP & 2006 & 5 & $\mathrm{nt}$ & $1-5$ \\
\hline 2005-2007 & Solothurn & $\mathrm{CH} 2$ & IP & 2006 & 50 & $9 / 11$ & $30-50$ \\
\hline
\end{tabular}

a $\mathrm{IP}=$ integrated production, $\mathrm{nt}=$ not tested, and na = not analyzed because no Cacopsylla picta were captured in this orchard.

${ }^{b}$ Results of polymerase chain reaction (PCR) testing. 
subsequent specific identification using the key of Ossiannilsson (32). During 2002 to 2007, regular insect captures were done from February to September each week or every 2 weeks. Because the insect captures started before the remigration of $C$. picta from overwintering hosts to the orchards, the first appearance of the remigrants in the orchard could be determined. From this time point, the orchard colonization period of the remigrants was calculated and weekly captured psyllids were grouped together for further data analysis. In this way, psyllid colonization classes of 2 days and 1 to 8 weeks were formed. In 2008 and 2009, psyllid captures for rearings and specific trials were concentrated in a particular orchard only in the known period of the population peak.

The natural infection rate with ' $\mathrm{Ca}$. P. mali' was determined in all individuals of $C$. picta collected during the regular collections at the different sites during their whole life cycle on apple. This mainly included overwintered adults (remigrants) and a small portion of new imagines just after hatching (emigrants) before their migration to the overwintering hosts.

Transmission trials with field-collected $\boldsymbol{C}$. picta. Remigrant individuals for transmission trials were collected mainly at four different sites (commercial orchards NW1 and NW1a and untreated orchards HA1 and MeStr) (Table 1) with infection rates $>50 \%$. Because new adults of $C$. picta were difficult to capture in sufficient quantities in the orchards, newly hatched adults from breedings on healthy apple plants were transferred prior to the transmission trial on micropropagated AP-infected apple plants for a 7-day acquisition feeding as described by Jarausch et al. (16). Groups of 5 to 20 specimens of both generations were caged on micropropagated healthy apple plants ('Golden Delicious' or 'Royal Gala') in glass vessels or cages for 2 to 4 weeks as described by Jarausch et al. (16). The vessels were closed with an anti-aphid mesh. Dead individuals were regularly picked up and immediately frozen at $-20^{\circ} \mathrm{C}$ until DNA extraction. Alive individuals were recollected from vessels after an incubation period of 2 weeks and from cages after an incubation period of 4 weeks and frozen at $-20^{\circ} \mathrm{C}$ until DNA extraction.

After the experiment, all test plants were treated with insecticides (Confidor at $0.16 \mathrm{~g} /$ liter or Calypso at $0.2 \mathrm{ml} / \mathrm{liter}$ ) and maintained in the greenhouse under insect-proof conditions. The test plants were regularly checked for symptom expression and analyzed by PCR for infection with ' $\mathrm{Ca}$. P. mali' 6 and 18 months after the end of the insect incubation period.

' $\mathrm{Ca}$. P. mali' detection in insect and plant material. A simplified cetyltrimethylammonium bromide (CTAB) method for DNA extraction based on a protocol of Maixner et al. (24) was used as follows for nucleic acid extraction from both insect and plant material.

Insect material. Single insects collected from apple and frozen at $-20^{\circ} \mathrm{C}$ were homogenized with a conical pestle (PP, $1.5 \mathrm{ml}$; Eppendorf, Hamburg, Germany) in 1.5-ml centrifugation tubes containing $100 \mu \mathrm{l}$ of extraction buffer $(2 \%$ CTAB, $1.4 \mathrm{M} \mathrm{NaCl}$, $20 \mathrm{mM}$ EDTA [pH 8.0], $100 \mathrm{mM}$ Tris- $\mathrm{HCl}$ [pH 8.0], and 2\% PVP 25 ) as grinding additive. After incubation at $60^{\circ} \mathrm{C}$ for $30 \mathrm{~min}$, the homogenate was extracted with chloroform and the nucleic acids were precipitated with isopropanol from the supernatant. The resulting pellet was washed with $70 \%$ ethanol and was finally resuspended in $25 \mu \mathrm{l}$ of sterile water and stored at $-20^{\circ} \mathrm{C}$.

Plant material. Total nucleic acids from field samples of apple as well as from test plants at the second test (18 months postinoculation) were extracted from $0.5 \mathrm{~g}$ of phloem of roots or shoots. Only if test plants were still too small (e.g., at the first test 6 months postinoculation) were $0.3 \mathrm{~g}$ of leaf midribs used for extraction. All plant material was extracted according to the protocol specified for insect material with the following modifications: phloem tissue or leaf midribs were ground in extraction buffer in enzyme-linked immunosorbent bags with a homogenizator (Bioreba, Switzerland) and the homogenate was transferred to 2-ml centrifugation tubes. Plant debris were precipitated by a centrifugation at low speed $(4 \mathrm{~min}, 2,200 \times g)$ and $1 \mathrm{ml}$ of the supernatant was further processed as mentioned above. The purified DNA was resuspended in $100 \mu \mathrm{l}$ of sterile water and stored at $-20^{\circ} \mathrm{C}$.

PCR analysis. PCR amplification of phytoplasma 16S rDNA was routinely carried out using universal ribosomal primers fU5/P7 $(23,35)$ on DNA samples from psyllids and universal ribosomal primers fU5/rU4 $(1,23)$ for plant material. All samples which gave a positive signal with universal primers were subjected to a new PCR with the nonribosomal-specific primers AP3/AP4 following the protocol for a ' $\mathrm{Ca}$. P. mali'-specific assay described by Jarausch et al. (19). Each PCR product $(8 \mu \mathrm{l})$ was analyzed by agarose gel electrophoresis and visualized under UV after ethidium bromide staining.

Quantitative real-time PCR. The phytoplasma concentrations in infected individuals of $C$. picta were determined by quantitative real-time PCR (qPCR) using the assay based on SYBR Green technology described by Jarausch et al. (18). This assay amplifies a specific gene fragment of ' $\mathrm{Ca}$. P. mali' with the primers AP3/AP4. A 10-fold dilution series from 1.0e +08 to $1.0 \mathrm{e}+01$ of a plasmid carrying the target gene fragment of ' $\mathrm{Ca}$. P. mali' was carried out in PCR-negative DNA extracts of $C$. picta for absolute quantification by the standard curve method. Naturally infected individuals of $C$. picta were used as a positive control. The qPCR assay was carried out on a Chromo4 Real-Time PCR detector (BioRad, München, Germany). The phytoplasma concentration determined in the sample was referred to as the phytoplasma concentration in one single individual.

Statistical analysis. All statistical analysis was performed using the biostatistics program $\mathrm{R}$ ( $\mathrm{R}$ development core team, 2.9.0). The specific analysis of these empiric data obtained during this study was based on the initial discrimination between normal or nonparametrical distribution of values by the Saphiro-Wilk normality test. The following calculations were adapted to the particular data sets.

Data obtained for the infection rate of $C$. picta in different orchards as well as data obtained for the phytoplasma concentration in remigrant $C$. picta gave a nonparametrical distribution; the Bartlett test of homogeneity of variances showed that variances were not homogeneous. A Kruskal-Wallis rank sum test was adopted to determine differences among means. If the KruskalWallis rank sum test showed differences among means, a Duncan test (confidence level $=95 \%$ ) was adopted to rank these differences.

\section{RESULTS}

Population dynamics, abundance, and natural infection rate of $\boldsymbol{C}$. picta. In order to study the incidence of AP related to the presence of psyllid populations, a wide spectrum of apple orchards with various degrees of infection with ' $\mathrm{Ca}$. P. mali' have been monitored over several years in different apple-growing regions of Germany, northern Switzerland, and eastern France. The AP infection status of each psyllid sampling site has been evaluated by visual diagnosis and molecular confirmation by PCR for those years where the insect captures have been performed (Table 1). The combined information of both data sets, visual inspection, and PCR testing was used to group the orchards into different infection classes (Table 1). In 51 of 52 sites, regular insect captures were carried out during 2002 to 2007 (Table 1). Due to various reasons such as uprooting of the orchard, modification of the agricultural practice, or unavailability of advisors, insect captures could not be done each year in every orchard.

Data about the different psyllid species captured in apple orchards of southwest Germany, northern Switzerland, and eastern France have already been published (13). Apart from C. mali and $C$. melanoneura, C. picta was the most important Cacopsylla 
sp. found on apple. This was also the case for the other orchards investigated in this study. The absolute number of individuals collected in the various areas during all years of study is summarized in Table 2. Despite a varying number of sites and frequencies among the different areas of this monitoring, an obvious concentration of this species occurred in a zone around southwest Germany, eastern France, and northern Switzerland whereas it was rarely present in the far northern and southeastern orchards in Germany. These variations in vector population densities coincide with geographic differences in the incidence of the disease (Table 1). The AP monitoring of the investigated orchards confirmed the estimations of plant health inspectors and previous data (37) that the incidence of the disease is very low in the north of Germany (Schleswig-Holstein and Rheinland) and highest in the southwestern part, including the Alsace region in France.
The results presented in Table 2 also reveal that the presence and abundance of $C$. picta underlay important variations among the years in all investigated areas. Hence, similarly for all regions, population densities were always much higher in 2003 and 2005 compared with all other years. The population dynamics of this monophagous psyllid on apple was representatively illustrated for the year 2005 for those zones with the highest abundance of insect population and incidence of the disease (Fig. 1). The first overwintered adults remigrating from their overwintering habitats arrive in apple orchards by mid-March (week 11), reach a maximum in the first half of April (week 13 to 15), and complete their life cycle on apple during the following 5 weeks (Fig. 1). The first imagines of the new generation hatch by mid-June, whirling within orchards for a further 2 weeks before they migrate to their overwintering sites.

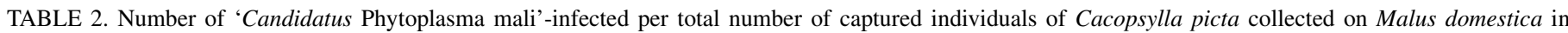
different apple-growing regions of Germany, eastern France (Alsace), and Northern Switzerland (Aargau, Solothurn) during 2002 to $2007^{\mathrm{a}}$

\begin{tabular}{|c|c|c|c|c|c|c|c|c|c|c|c|c|c|}
\hline \multirow[b]{3}{*}{ Region } & \multicolumn{13}{|c|}{ Number of sites (Sites) and numbers of infected individuals/captured individuals (Ratio) } \\
\hline & \multicolumn{2}{|c|}{2002} & \multicolumn{2}{|c|}{2003} & \multicolumn{2}{|c|}{2004} & \multicolumn{2}{|c|}{2005} & \multicolumn{2}{|c|}{2006} & \multicolumn{2}{|c|}{2007} & \multirow[b]{2}{*}{ Total $^{\mathrm{b}}$} \\
\hline & Sites & Ratio & Sites & Ratio & Sites & Ratio & Sites & Ratio & Sites & Ratio & Sites & Ratio & \\
\hline Schleswig-Holstein & nt & $\ldots$ & 2 & $0 / 0$ & 2 & $0 / 0$ & 2 & $0 / 1$ & nt & $\cdots$ & $\mathrm{nt}$ & $\ldots$ & $0 / 1$ \\
\hline Rheinland & 1 & $0 / 3$ & 1 & $0 / 9$ & 1 & $0 / 3$ & 1 & $0 / 5$ & nt & $\ldots$ & nt & $\ldots$ & $0 / 20$ \\
\hline Rheinhessen & 3 & $0 / 10$ & 5 & $5 / 73$ & 2 & $0 / 1$ & 2 & $0 / 13$ & nt & $\ldots$ & nt & $\ldots$ & $5 / 97$ \\
\hline Vorderpfalz & 10 & $20 / 187$ & 12 & $67 / 574$ & 8 & $13 / 89$ & 6 & $32 / 269$ & 4 & $2 / 17$ & 5 & $4 / 17$ & $138 / 1,153$ \\
\hline Südpfalz & nt & $\ldots$ & nt & $\ldots$ & nt & $\ldots$ & 4 & $3 / 31$ & 5 & $2 / 27$ & 5 & $2 / 26$ & $7 / 84$ \\
\hline Nordbaden & 3 & $4 / 21$ & 4 & $17 / 149$ & 2 & $3 / 27$ & 2 & $14 / 140$ & 2 & $0 / 2$ & 2 & $0 / 1$ & $38 / 340$ \\
\hline Mittelbaden & 1 & $0 / 0$ & 1 & $0 / 26$ & $\mathrm{nt}$ & $\ldots$ & 2 & $21 / 263$ & nt & $\ldots$ & $\mathrm{nt}$ & $\ldots$ & $21 / 289$ \\
\hline Südbaden & $\mathrm{nt}$ & $\ldots$ & nt & $\ldots$ & nt & $\ldots$ & 1 & $3 / 20$ & 1 & $0 / 1$ & nt & $\ldots$ & $3 / 21$ \\
\hline Weinsberg & $\mathrm{nt}$ & $\ldots$ & 1 & $0 / 4$ & 1 & $0 / 1$ & 1 & $0 / 1$ & $\mathrm{nt}$ & $\ldots$ & $\mathrm{nt}$ & $\ldots$ & $0 / 6$ \\
\hline Bodensee & $\mathrm{nt}$ & $\ldots$ & 4 & $0 / 0$ & 5 & $0 / 4$ & 3 & $1 / 6$ & 3 & $0 / 2$ & nt & $\ldots$ & $1 / 12$ \\
\hline Alsace & $\mathrm{nt}$ & $\ldots$ & $\mathrm{nt}$ & $\ldots$ & $\mathrm{nt}$ & $\ldots$ & 3 & $22 / 156$ & 3 & $0 / 1$ & 3 & $0 / 0$ & $22 / 157$ \\
\hline Aargau & $\mathrm{nt}$ & $\ldots$ & $\mathrm{nt}$ & $\ldots$ & $\mathrm{nt}$ & $\ldots$ & 1 & $5 / 55$ & 1 & $0 / 4$ & 1 & $1 / 3$ & $6 / 62$ \\
\hline Solothurn & $\mathrm{nt}$ & $\ldots$ & $\mathrm{nt}$ & $\ldots$ & $\mathrm{nt}$ & $\ldots$ & 1 & $0 / 9$ & 1 & $0 / 2$ & 1 & $0 / 0$ & $0 / 11$ \\
\hline Total & $\ldots$ & $24 / 221$ & $\ldots$ & $89 / 835$ & $\ldots$ & $16 / 125$ & $\ldots$ & $101 / 969$ & $\ldots$ & $4 / 56$ & $\ldots$ & $7 / 47$ & $241 / 2,253$ \\
\hline
\end{tabular}

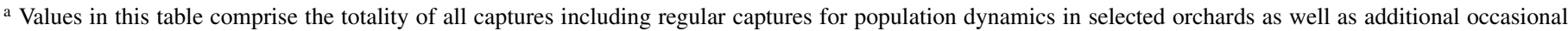
captures for trials on abandoned sites; $\mathrm{nt}=$ not tested.

b Total numbers of infected/captured individuals.

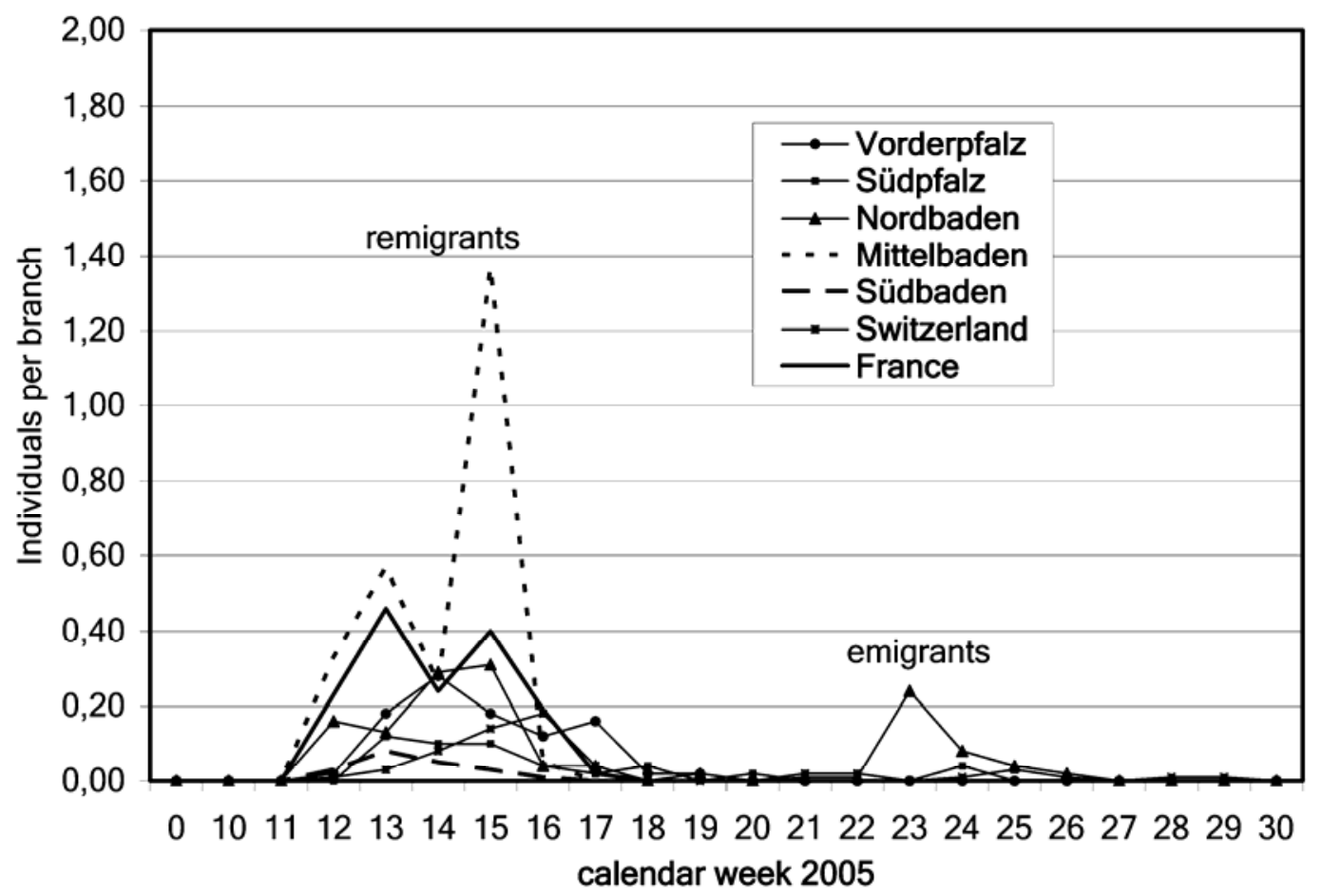

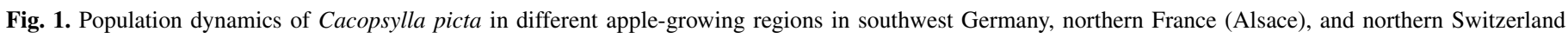
(Aargau, Solothurn) 2005. 
A reliable estimation of the natural infection rate of $C$. picta could only be achieved if a substantial number of individuals could be tested. Whereas no infected individual was captured in the north of Germany, the highest infection rates occurred in those regions with more important populations of $C$. picta, reaching percentages of 11 to $15 \%$ for Vorderpfalz, $11 \%$ for Nordbaden, and $14 \%$ for the Alsace region. Over the years, a rather stable percentage of $\approx 10 \%$ of infected individuals was found in these regions. Therefore, these data indicate a correlation between the incidence of AP in a given region and the infection rate of the $C$. picta population in this region.

Relationship of the infection rate of overwintered $C$. picta and the infection status of the orchard. A more detailed analysis of the relationship between the AP infection rate of the orchard and the corresponding portion of infected $C$. picta is shown in Table 3. The total spectrum of investigated sites included commercial orchards with integrated production or organic farming as well as field sites of abandoned or scattered orchards without any treatment. The infection rates in orchards with integrated production varied from $<1$ to $>50 \%$. The investigated organically cultivated orchards showed lower infection rates of only $5 \%$. In contrast, all abandoned or scattered sites were highly AP infected in all different areas. Thus, based on visual monitoring and PCR detection, all investigated sites could be assigned to at least seven classes of infection variously dispersed among the different types of orchards (Table 1). Although the estimation of the infection rate of overwintered $C$. picta captured in the orchards of the different infection classes could only be regarded as reliable for those where a substantial number of individuals could be tested, the infection rates were 5 to $14 \%$ yielding a mean infection rate of $10.6 \%$. The statistical analysis of the data revealed no relationship between infection rate of $C$. picta and infection of the orchard by ' $C a$. P. mali' (Kruskal-Wallis $\chi^{2}=$ 16.2185 , df $=11, P=0.1332$ ). The general comparison between the type of orchards (abandoned, integrated production, or organic farming) showed a tendency of higher infection rates of C. picta in abandoned orchards which, however, were not statistically significant (Kruskal-Wallis $\chi^{2}=4.7151$, df $=2, P=0.09465$ ) (Fig. 2).

Gender balance of captured and infected $\boldsymbol{C}$. picta. The separation of all captured and tested $C$. picta with respect to their sex allowed us to follow the evolution of the gender balance of collected overwintered individuals by time and to analyze the gender balance of infected remigrants. Evolution of the gender balance of all overwintered C. picta by time for the years 2003 and 2005, where a substantial number of data were available for this analysis, is demonstrated in Figure 3. A similar tendency appears for both years: an equal gender balance at the beginning of the remigration period followed by a clear predominance of captured females with advanced colonization time (Fig. 3). A detailed analysis focusing on the ratio of captured and infected males and females and differentiating among cultivated and uncultivated sites is presented in Table 4 . The recapitulation for all years resulted in a similar percentage of $10 \%$ infected males compared with $11 \%$ infected females for both culture practices. A Kruskal-Wallis test did not reveal significant differences between the infection rate of males in cultivated or uncultivated orchards and the infection rate of females, respectively (Kruskal-Wallis $\chi^{2}=5.2439$, df $=3, P=0.1548$ ). A higher number of females was constantly captured, yielding an overall male/female ratio of 1:1.4 in cultivated orchards and 1:1.5 in uncultivated orchards. Although the same gender balance also was observed in cultivated orchards for infected individuals, a slightly higher portion of females was infected in uncultivated orchards (ratio 1:2).

Transmission trials with overwintered adults of $\boldsymbol{C}$. picta. In order to elucidate the potential vector capacity of field-collected remigrants of $C$. picta, transmission trials were conducted under controlled conditions. A summary of these trials of a 6-year

\section{Boxplot}

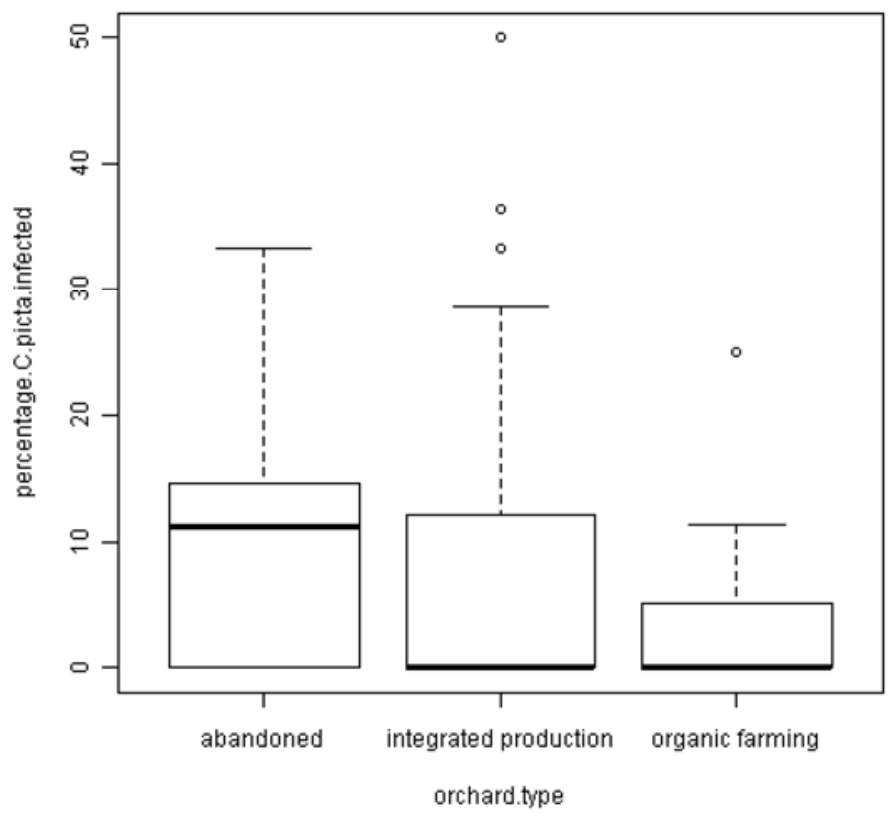

Fig. 2. Distribution of infected remigrants of Cacopsylla picta in different types of orchards. Means of the percentage of infected C. picta (males and females) were compared by a Kruskal-Wallis rank sum test (Kruskal-Wallis $\chi^{2}=4.7151, \mathrm{df}=2, P$ value $\left.=0.09465\right)$. No significant difference was observed.

TABLE 3. Relationship between infection status of the orchard and number of phytoplasma-infected overwintered individuals of Cacopsylla picta based on captures made during 2002 to $2008^{a}$

\begin{tabular}{|c|c|c|c|c|c|c|}
\hline Orchard type & $\begin{array}{l}\text { Number of } \\
\text { sites }\end{array}$ & $\begin{array}{l}\text { Years of psyllid } \\
\text { captures }\end{array}$ & $\begin{array}{l}\text { AP infection class of } \\
\text { the orchard }\end{array}$ & $\begin{array}{l}\text { Number of } C \text {. picta } \\
\text { individuals tested }\end{array}$ & $\begin{array}{l}\text { Number of PCR- } \\
\text { positive } C \text {. picta }\end{array}$ & $\begin{array}{l}\text { Infection of } \\
\text { C. picta }(\%)\end{array}$ \\
\hline Organic farming & 1 & 2004-2005 & $<1$ & 1 & 0 & 0 \\
\hline Organic farming & 4 & 2002-2005 & $1-5$ & 112 & 8 & 7.1 \\
\hline Integrated production & 1 & $2005-2006$ & $<1$ & 17 & 0 & 0 \\
\hline Integrated production & 12 & 2002-2008 & $1-5$ & 268 & 34 & 12.7 \\
\hline Integrated production & 8 & 2002-2008 & $10-20$ & 361 & 28 & 7.8 \\
\hline Integrated production & 3 & $2002-2005$ & $20-30$ & 135 & 7 & 5.2 \\
\hline Integrated production & 2 & $2005-2006$ & $30-50$ & 28 & 2 & 7.1 \\
\hline Integrated production & 1 & 2002-2005 & $>50$ & 119 & 15 & 12.6 \\
\hline Integrated production & 1 & $2007-2008$ & $>75$ & 21 & 3 & 14.3 \\
\hline Abandoned (untreated) & 9 & 2002-2008 & $25-50$ & 688 & 81 & 11.8 \\
\hline Abandoned (untreated) & 5 & $2002-2003$ & $>50$ & 76 & 7 & 9.2 \\
\hline Abandoned (untreated) & 1 & 2002-2006 & $>75$ & 441 & 56 & 12.7 \\
\hline Total & 48 & $\ldots$ & $\ldots$ & 2,267 & 241 & 10.6 \\
\hline
\end{tabular}

a $\mathrm{AP}=$ apple proliferation and $\mathrm{PCR}=$ polymerase chain reaction. 
repetition period is shown in Table 5. The results of 2002 have already been published $(16,17)$. The data clearly show that successful transmission was not only an occasional event but also could be repeated each year. Plant material as well as experimental conditions were kept as homogeneous as possible; thus, the differences in transmission success must be attributed to the heterogeneity of field-collected specimens. However, despite these variations, successful transmission occurred each year, yielding rates of 8 to $45 \%$. Although not all phytoplasma-infected individuals of $C$. picta were able to transmit ' $C a$. P. mali' under the applied experimental conditions, the presence of infected $C$. picta in a trial corresponded generally well to the transmission events. Thus, the results demonstrate the high vector capacity of overwintered C. picta.

Acquisition and transmission capacity of new imagines of C. picta. Likewise, the acquisition of ' $\mathrm{Ca}$. P. mali' and its subsequent transmission to healthy test plants was studied with new individuals from breedings of C. picta in the greenhouse. As for overwintered adults, successful transmission occurred in each year of repetition (Table 6). Despite the more or less homogeneous insect material from breedings, transmission rates varied between 2 and $20 \%$ among the years of investigation. In these
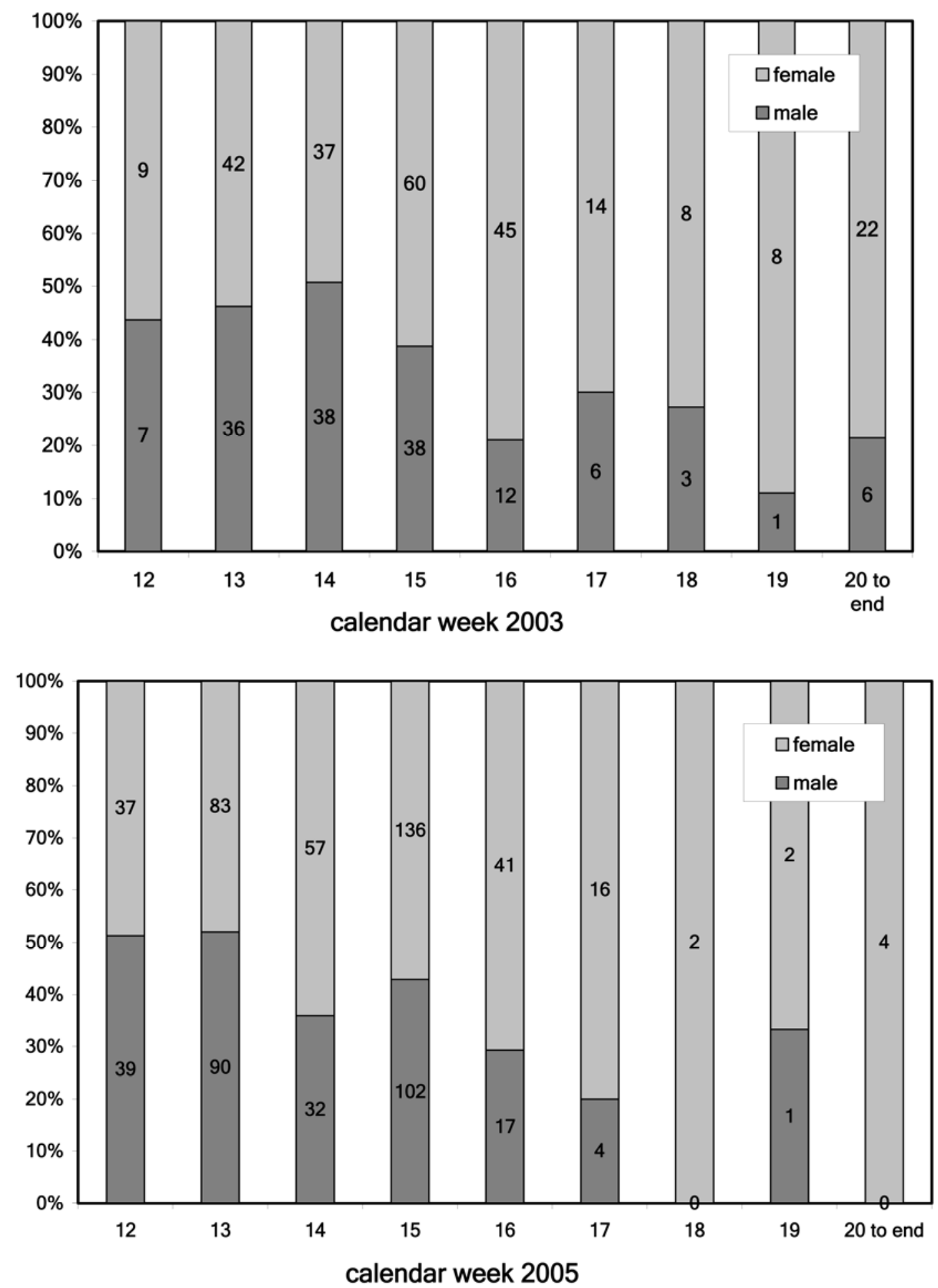

Fig. 3. Trend of gender balance changes by time of remigrant adults of Cacopsylla picta in two different years of high population densities. Only data from orchards in which $C$. picta regularly was caught were analyzed; absolute numbers are given inside the columns. 
trials, a much higher portion of PCR-positive individuals was not able to transmit compared with naturally infected overwintered adults. However, transmission events were likewise correlated to the presence of infected $C$. picta.

Concentration of ' $\boldsymbol{C a}$. P. mali' in infected remigrants of $\boldsymbol{C}$. picta. The phytoplasma titer was measured by qPCR in infected individuals of $C$. picta at different periods after the first remigrants were found on apple. The first infected specimens of $C$. picta were already found 2 days after the first appearance in the orchard. All infected individuals captured during the subsequent weekly collections were grouped for data analysis in classes of 1 to 8 weeks of orchard colonization. By this means, the development of the phytoplasma titer could be followed for a period of at least 8 weeks. The mean concentrations deviated between $2.0 \mathrm{e}+$ 08 and $6.0 \mathrm{e}+08$ copies per individual, except for a considerably high value of circa $9.0 \mathrm{e}+08$ copies after 8 weeks (Fig. 4). However, the graph did not show a clear rise of the phytoplasma load with increasing orchard colonization time. The mean phytoplasma concentration varied consistently among the weeks (e.g., the statistical analysis revealed differences in phytoplasma load between individuals captured after 8 weeks with those captured after 2 days, 1 week, and 6 weeks, respectively, but not with those caught after 2 weeks) (Fig. 4). Thus, the phytoplasma titer measured in individuals already collected 2 days after the first appearance was as high as for those specimens tested after 6 weeks, indicating that overwintered $C$. picta arrive already highly phytoplasma loaded in the orchards when remigrating from their overwintering sites in early spring (Table 7).

\section{DISCUSSION}

The epidemiology of a disease underlies multiple biotic and abiotic factors which interact in manifold variable conditions. An epidemiological cycle is a complex system which requires an extensive survey of its different components during several years. Hence, the main objective of this study was to collect precise and repetitive data over several years in order to provide a comprehensive description of the epidemiology of ' $\mathrm{Ca}$. P. mali' and its main vector in Germany and neighboring regions, $C$. picta. By the selection of many multifaceted sites and surroundings, we intended to disclose differences and common aspects of the epidemiology and etiology of AP and to work out general conclusions for the spread of this disease and its management. Until now, only a few reports exist about the epidemiology of AP disease and the search for its vectors, and all these studies are limited to the description of a particular situation in one defined, local area $(5,9,10,26,40-42)$. The spectrum of sites investigated during this study included orchards in various areas with specific biogeographical and climatic properties. As published previously, $C$. picta and $C$. melanoneura are actually the most abundant psyllid species in apple orchards of the studied regions (13). However, $C$. melanoneura was not found to be infected with ' $\mathrm{Ca}$. P. mali' and, therefore, the population of $C$. melanoneura in Germany and neighboring regions is regarded as being unable to vector the disease (27). In contrast, the overall survey showed a clear coherence between the incidence of ' $\mathrm{Ca}$. P. mali' and the presence of $C$. picta: a low incidence and absence or very few $C$.

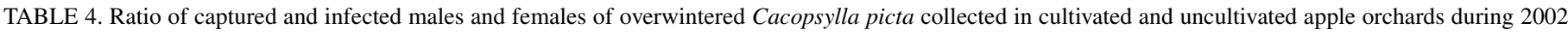
to 2009

\begin{tabular}{|c|c|c|c|c|c|}
\hline Year & Orchard type & Male infected/total (\%) & Female infected/total (\%) & Male/female captured & Male/female infected \\
\hline \multirow[t]{2}{*}{2002} & Cultivated & $0 / 17(0)$ & $5 / 43(11.6)$ & $1: 2.5$ & $0: 5$ \\
\hline & Uncultivated & $1 / 40(0.03)$ & $16 / 85(18.8)$ & $1: 2.1$ & $1: 16$ \\
\hline \multirow[t]{2}{*}{2003} & Cultivated & $12 / 115(10.4)$ & $9 / 133(6.8)$ & $1: 1.2$ & $1: 0.75$ \\
\hline & Uncultivated & $24 / 236(10.2)$ & $44 / 349(12.6)$ & $1: 1.5$ & $1: 1.8$ \\
\hline \multirow[t]{2}{*}{2004} & Cultivated & $4 / 16(25)$ & 4/38 (10.5) & $1: 2.4$ & $1: 1$ \\
\hline & Uncultivated & $2 / 25(8)$ & $6 / 45(13.3)$ & $1: 1.8$ & $1: 3$ \\
\hline \multirow[t]{2}{*}{2005} & Cultivated & $27 / 279(9.7)$ & $32 / 360(8.9)$ & $1: 1.3$ & $1: 1.2$ \\
\hline & Uncultivated & $19 / 145(13.1)$ & $23 / 188(12.2)$ & $1: 1.3$ & $1: 1.2$ \\
\hline \multirow[t]{2}{*}{2006} & Cultivated & $0 / 9(0)$ & $1 / 15(6.7)$ & $1: 1.7$ & $0: 1$ \\
\hline & Uncultivated & $0 / 7(0)$ & $3 / 25(12)$ & $1: 3.6$ & $0: 3$ \\
\hline \multirow[t]{2}{*}{2007} & Cultivated & $0 / 2(0)$ & $2 / 10(20)$ & $1: 5$ & $0: 2$ \\
\hline & Uncultivated & $2 / 14(14.3)$ & $3 / 21(14.3)$ & $1: 1.5$ & $1: 1.5$ \\
\hline \multirow[t]{2}{*}{2008} & Cultivated & $0 / 20(0)$ & 4/27 (14.8) & $1: 1.4$ & $0: 4$ \\
\hline & Uncultivated & $1 / 4(25)$ & $1 / 4(25)$ & $1: 1$ & $1: 1$ \\
\hline 2009 & Cultivated & $3 / 16(18.8)$ & $1 / 42(2.4)$ & $1: 2.6$ & $1: 0.33$ \\
\hline Total & Cultivated & $46 / 474(9.7)$ & $58 / 668(8.7)$ & $1: 1.4$ & $1: 1.3$ \\
\hline Total & Uncultivated & $49 / 471(10.4)$ & $96 / 717(13.4)$ & $1: 1.5$ & $1: 2$ \\
\hline Total & $\ldots$ & $95 / 945(10.1)$ & $154 / 1,385(11.1)$ & $1: 1.5$ & $1: 1.6$ \\
\hline
\end{tabular}

TABLE 5. Summary of transmission trials with overwintered adults of Cacopsylla picta conducted in climatic chambers in the greenhouse during 2002 to 2007

\begin{tabular}{|c|c|c|c|c|c|c|}
\hline Overwintered $C$. picta ${ }^{\mathrm{a}}$ & 2002 & 2003 & 2004 & 2005 & 2006 & 2007 \\
\hline PCR + insects/total recollected insects tested & $11 / 92$ & $32 / 255$ & $8 / 62$ & $22 / 256$ & $3 / 34$ & $6 / 32$ \\
\hline PCR + plants/plants tested & $5 / 11$ & $12 / 36$ & $1 / 13$ & $4 / 32$ & $2 / 24$ & $4 / 12$ \\
\hline Transmission $(\%)$ & 45 & 33 & 8 & 13 & 8 & 33 \\
\hline
\end{tabular}

a $\mathrm{PCR}=$ polymerase chain reaction.

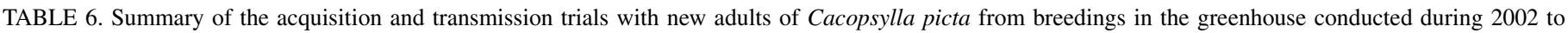
2007

\begin{tabular}{|c|c|c|c|c|c|c|}
\hline New adults of $C$. picta ${ }^{\mathrm{a}}$ & 2002 & 2003 & 2004 & 2005 & 2006 & 2007 \\
\hline PCR + insects/total recollected insects tested ${ }^{b}$ & $1 / 56$ & $26 / 135$ & $5 / 58$ & $28 / 261$ & $9 / 150$ & $146 / 365$ \\
\hline PCR + plants/plants tested & $1 / 5$ & $4 / 28$ & $1 / 21$ & $1 / 23$ & $4 / 25$ & $1 / 49$ \\
\hline Transmission $(\%)$ & 20 & 14 & 5 & 4 & 16 & 2 \\
\hline
\end{tabular}

a $\mathrm{PCR}=$ polymerase chain reaction.

${ }^{\mathrm{b}}$ All individuals tested after acquisition feeding and subsequent latency period during transmission. 
picta in the far northern part and in southeastern Germany compared with a concentration of the disease and the vector along a southwestern axis comprising the southwestern parts of Germany and adjacent areas of France (Alsace) and Switzerland (Aargau and Solothurn). Regardless of the highly unequal population densities, the population dynamics were similar in the different regions and were in general agreement with the life cycle of $C$. picta described for other regions (26). However, we consistently captured the first remigrants in the second half of March, which is at least 2 weeks earlier than in other reports $(26,30)$. This might be due to the more extensive captures carried out in the present study or to climatic differences between the studied regions (e.g., Trentino in northern Italy).

Although a good correlation between the incidence of the disease and the proportion of infected individuals was observed on a regional scale, yielding a relative constant mean percentage $\approx 10 \%$ of naturally infected overwintered $C$. picta every year, a more detailed analysis of the correlation between the infection status of a particular orchard and the abundance of infected $C$. picta revealed a more complex and heterogeneous situation. No clear relationship occurred in terms of orchard type, infection rate of the orchard with ' $\mathrm{Ca}$. P. mali', and abundance and infection rate of $C$. picta. Thus, in IP orchards with low AP infection, we found an important population of $C$. picta and a high number of infected individuals and, vice versa, at some highly infected abandoned sites only few specimens were collected. We conclude that those infected $C$. picta we found in a particular orchard already acquired the agent in the previous year elsewhere and they did not necessarily go back to the orchard where they were born or where they acquired the phytoplasma. On the other hand, the orchard type does not really influence the frequency of the vector; only when intensive spraying starts due to cultural practices in some orchards is the population reduced. However, when overwintered adults of $C$. picta arrive on apple in early spring, spraying has not yet started in our regions and, thus, the psyllid can move around unimpaired. Although the gender

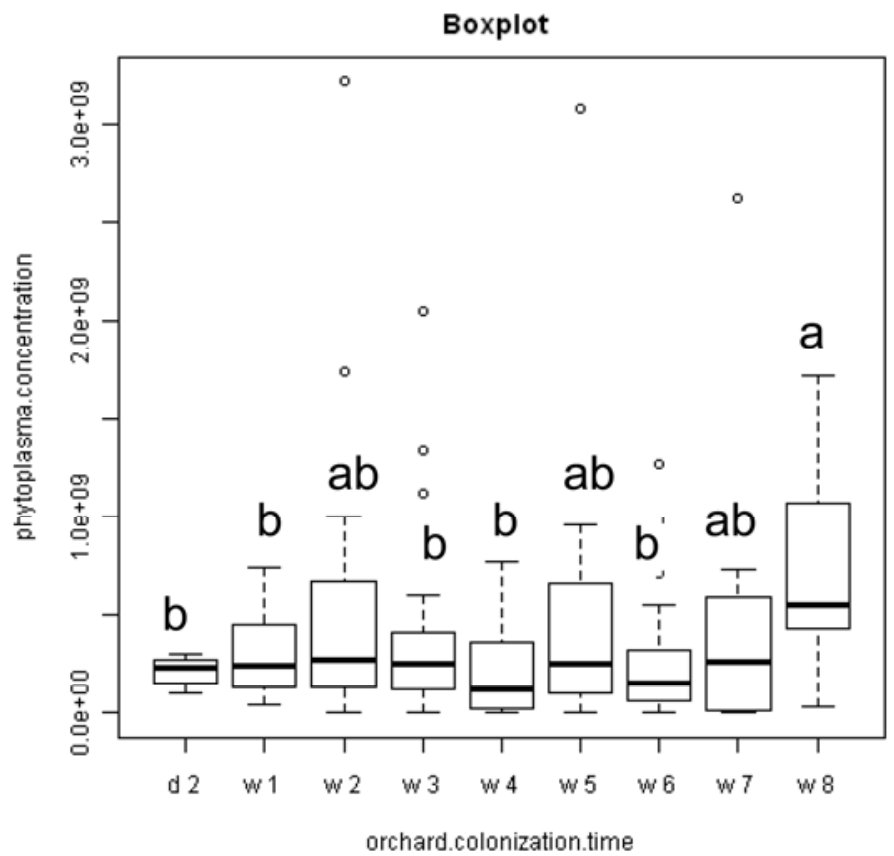

Fig. 4. Mean phytoplasma concentration in overwintered individuals of Cacopsylla picta captured in the orchards at different periods after remigration in spring (psyllid colonization time in the orchard $=2$ days to 8 weeks). Boxplot of means of phytoplasma concentration at different times compared by a Kruskal-Wallis rank sum test (Kruskal-Wallis $\chi^{2}=20.6716$, df $=8$, $P$ value $=0.008073)$. Letters above each column indicate the differences evidenced by a subsequent Duncan test; confidence level $=0.95$, variation coefficient $=125.35 \%$. balance was equal at the beginning of the remigration period, females showed an increased life span and stayed up to 2 months in the orchards. Thus, the total number of females was higher regardless of the orchard type. Interestingly, the ratio of infected males to infected females was similar to the ratio of captured males to females, resulting in a similar infection rate of both genders. This indicates that both genders acquire the phytoplasma equally well. Furthermore, the analysis of the concentration of ' $C a$. P. mali' in overwintered $C$. picta from the first arrival until the last collected specimens showed that the first remigrants already arrived with a high phytoplasma load and the titer did not significantly rise in individuals collected later. This leads to the conclusion that overwintered adults have already acquired the phytoplasma during larval development or as emigrant adults in the previous year. The phytoplasma multiplies in the insect during the whole overwintering period, also confirming for $C$. picta the hypothesis of winter retention of the pathogen which has already been described for $C$. melanoneura (42) and for $C$. pruni, the vector of ' $\mathrm{Ca}$. P. prunorum' $(6,43)$. The hypothesis of primary pathogen ingestion by new adults of $C$. picta is also supported by data recently published by Mayer and co-workers (28-30), who found that emigrants of $C$. picta were particularly attracted by infected apple trees before migrating to their overwintering hosts.

Comparative data in terms of the natural infection status of $C$. picta are rare. Only Carraro et al. (5) determined the proportion of phytoplasma-positive and inoculative $C$. picta in groups of overwintering adults and of the springtime generation. Their cumulative data showed that $45 \%$ of remigrants in spring carried the phytoplasma compared with $14 \%$ infection in groups of the springtime generation. However, these data, based on calculations in groups of psyllids, cannot be directly compared with our quantification in individuals of C. picta. Furthermore, the vector situation in the area investigated by Carraro and colleagues (5) seems to be quite different because the population densities in our regions were much lower and the portion of new adults among the total numbers of insects tested was negligible, which was also reported by other authors (10). However, the detection of an agent in the insect's body by molecular means does not yet prove that it is a real vector $(25,44)$. Therefore, in addition to the direct determination of the natural infection status in overwintered adults, we proved the vector capacity of both generations of $C$. picta within specific transmission trials under experimental conditions. We could clearly show that both generations were able to transmit the phytoplasma repeatedly to healthy test plants but with a higher efficiency by overwintered adults. Oppositional results were reported by Mattedi et al. (26) and Carraro et al. (5), who found higher transmission rates with specimens of the new generation of C. picta. However, this obvious contradiction can be based on two assumptions: (i) the acquisition and transmission conditions in our trails were not ideal, at least for new adults, or (ii) the popu-

TABLE 7. Quantification of 'Candidatus Phytoplasma mali' in remigrants of Cacopsylla picta at their first appearance in the orchards in different applegrowing regions

\begin{tabular}{lll}
\hline $\begin{array}{l}\text { Mean phytoplasma } \\
\text { copies/individual }\end{array}$ & Region & $\begin{array}{c}\text { Date of first } \\
\text { appearance }\end{array}$ \\
\hline $4.07 \mathrm{e}+08$ & Südpfalz & 20 March 2005 \\
$1.38 \mathrm{e}+08$ & Nordbaden & 24 March 2005 \\
$1.69 \mathrm{e}+08$ & Nordbaden & 24 March 2005 \\
$7.05 \mathrm{e}+07$ & Nordbaden & 24 March 2005 \\
$2.32 \mathrm{e}+08$ & Nordbaden & 24 March 2005 \\
$5.08 \mathrm{e}+08$ & Nordbaden & 24 March 2005 \\
$7.23 \mathrm{e}+08$ & Nordbaden & 24 March 2005 \\
$3.25 \mathrm{e}+08$ & Südbaden & 20 March 2005 \\
$4.39 \mathrm{e}+08$ & Switzerland & 21 March 2005 \\
$1.34 \mathrm{e}+08$ & Alsace & 24 March 2005 \\
$2.91 \mathrm{e}+08$ & Alsace & 24 March 2005 \\
$4.21 \mathrm{e}+08$ & Alsace & 24 March 2005 \\
\hline
\end{tabular}


lations of C. picta in areas located north and south of the Alps are different. However, all three studies with new adults of $C$. picta demonstrate that the latent period or incubation time necessary from initial acquisition to the ability to transmit the phytoplasma can be very short (e.g., a few weeks), whereas it has been reported for another psyllid vector, C. pruni, that the transmission of ' $\mathrm{Ca}$. P. prunorum' takes place after the overwintering period of several months (43). Data reported by Pedrazzoli et al. (33) further demonstrated that new adults of $C$. picta can efficiently acquire the phytoplasma from test plants but phytoplasma multiplication to high titers happens only in few individuals within 2 weeks postinoculation. Although acquisition efficiencies of new adults were much lower in our trials, the data confirm the low transmission efficiency of new adults, probably due to the low number of individuals which were sufficiently highly phytoplasma loaded. We suppose that the physiology of the individual determines its vector capacity. However, the simple fact that successful transmission occurred with new adults of $C$. picta and that, for some individuals, a rather short latency period is sufficient to obtain an important phytoplasma titer for transmission indicate that emigrant as well as remigrant adults of $C$. picta are vectors for ' $C a$. P. mali'. In agreement with Carraro et al. (5), we conclude that $C$. picta is able to transmit the pathogen during the entire period where it resides on apple and, in contrast to $C$. pruni (43), we propose a polycyclic vector model for $C$. picta: the overwintered individuals are more numerous vectors because they already acquired the phytoplasma in the previous year and the agent had a long latency period to multiply in the insect's body but a certain portion of the new generation already becomes infective and transmits the pathogen in the same season before migrating to overwintering hosts.

It is still unclear which is the most critical and most efficient period and habitat for $C$. picta to acquire the phytoplasma and what happens during the overwintering period; therefore, it is difficult to give general control recommendations. However, our study demonstrated that the situation in a fruit crop area can be rather variable with regard to infection status, population density, wild inoculum sources in the surroundings, agricultural practices, and so on, and that the infection of an orchard is not an immediate result of 1 year but reflects the sum of pathogen-related infection events over a longer, multiyear period. Consequently, control strategies on a single orchard level are not sufficient. We recommend comprehensive control management on a regional level, including control of the remigrants, prevention of the larval development, and impairment of the motility of new adults. Considering this aspect, previous studies have shown that newly hatched adults of $C$. picta were more attracted by the odor of infected trees compared with healthy ones $(28,30)$. In this period, classical control measures are critical; therefore, alternative control strategies such as use of biological traps based on the release of infochemicals (28) could be envisaged. A further advantage of such control is that it could be used regardless of the different orchard types and particular cultural practices of neighboring areas and country-specific plant-protection guidelines.

In conclusion, this study provided important data for a better understanding of the epidemiology of AP, not only in Germany but also in general. $C$. picta proved to be a very efficient vector and has to be regarded as main vector in all regions where it is present. Although the disease is spread in a polycyclic manner, the main spread takes place by highly infected overwintered adults on a regional scale. In consequence, control strategies against the spread of AP also have to be applied on a regional scale and include consequent uprooting of infected trees as well as vector control.

\section{ACKNOWLEDGMENTS}

We thank the Rhein-Pfalz-Wohnen GmbH (FELR), the province of Trentino, Italy (project SMAP), and the European Community
(INTERREG IIIA) for funding this study continuously during the entire period; U. Harzer, I. Lampe, A. Fried, E. Schell, G. Henkel, M. Hellmann, W. Dahlbender, G. Hensel, W. Hein, I. Nikusch, H. Gernoth, H. Schneider, M. Trautmann, B. Strobel, D. Hagl, H. Bentz, O. Eicher, and J. Brägger for psyllid collections; and D. König for advice in statistical analysis.

\section{LITERATURE CITED}

1. Ahrens, U., and Seemüller, E. 1992. Detection of DNA of plant pathogenic mycoplasmalike organisms by a polymerase chain-reaction that amplifies a sequence of the 16S RNA gene. Phytopathology 82:828-832.

2. Anonymous. 1991. European guidelines for organic production 2092/91.

3. Anonymous. 2006. Richtlinie für den kontrollierten, Integrierten Anbau von Obst und Gemüse in der Bundesrepublik Deutschland. II. überarbeitete und erweiterte Richtlinie, Stand. Fachgruppe Obstbau/ Gemüsebau. www.obstbau.org

4. Canik, D., and Ertunc, F. 2007. Distribution and molecular characterization of apple proliferation phytoplasma in Turkey. Bull. Insectol. 60:335-336.

5. Carraro, L., Ferrini, F., Ermacora, P., Loi, N., and Labonne, G. 2008. Infectivity of Cacopsylla picta (Syn. C. costalis), vector of 'Candidatus Phytoplasma mali' in North East Italy. Acta Hortic. 781:403-408.

6. Carraro, L., Ferrini, F., Labonne, G., Ermacora, P., and Loi, N. 2004. Seasonal infectivity of Cacopsylla pruni, vector of European stone fruit yellows phytoplasma. Ann. Appl. Biol. 144:191-195.

7. Carraro, L., Loi, N., and Ermacora, P. 2001. Transmission characteristics of the European stone fruit yellows phytoplasma and its vector Cacopsylla pruni. Eur. J. Plant Pathol. 107:695-700.

8. Čermák, V., and Lauterer, P. 2008. Overwintering of psyllids in South Moravia (Czech Republic) with respect of the vectors of the Apple Proliferation cluster phytoplasmas. Bull. Insectol. 61:147-148.

9. Delic, D., Martini, M., Ermacora, P., Carraro, L., and Myrta, A. 2005. first report of fruit tree phytoplasmas and their psyllid vectors in Bosnia and Herzegovina. J. Plant Pathol. 41:195-203.

10. Fialova, R., Navratil, M., Valova, P., and Lauterer, P. 2008. Molecular tests to determine apple proliferation phytoplasma presence in psyllid vectors from apple tree orchards in the Czech Republic. Acta Hortic. 781:471-475.

11. Frisinghelli, C., Delaiti, L., Grando, M. S., Forti, D., and Vindimian, M. E. 2000. Cacopsylla costalis (Flor 1861), as a vector of apple proliferation in Trentino. J. Phytopathol. 148:425-431.

12. Jarausch, B. 2003. Welche Rolle spielen Blattsaugerarten bei der Übertragung von Apfeltriebsucht-Phytoplasmen in deutschen Apfelanlagen? Obstbau 4:205-206.

13. Jarausch, B., Burckhardt, D., Lauterer, P., and Jarausch, W. 2009. Psyllids (Hemiptera, Psylliodea) captured in commercial apple and stone fruit orchards in southwest Germany, eastern France and northwest Switzerland. Mitt. Schweiz. Entomol. Ges. 82:205-215.

14. Jarausch, B., Fuchs, A., Schwind, N., Krczal, G., and Jarausch, W. 2007. Cacopsylla picta as most important vector for 'Candidatus Phytoplasma mali' in Germany and neighbouring regions. Bull. Insectol. 60:189-190.

15. Jarausch, B., and Jarausch, W. 2010. Psyllid vectors and their control. Pages 250-271 in: Phytoplasmas-Genomes, Plant Hosts and Vectors. P. G. Weintraub and P. Jones, eds. CABI, England.

16. Jarausch, B., Schwind, N., Jarausch, W., and Krczal, G. 2004. Overwintering adults and springtime generation of Cacopsylla picta (synonym C. costalis) can transmit apple proliferation phytoplasmas. Acta Hortic. 657:409-413.

17. Jarausch, B., Schwind, N., Jarausch, W., Krczal, G., Dickler, E., and Seemüller, E. 2003. First report of Cacopsylla picta as a vector of apple proliferation phytoplasma in Germany. Plant Dis. 87:101.

18. Jarausch, W., Peccerella, T., Schwind, N., Jarausch, B., and Krczal, G. 2004. Establishment of a quantitative real-time PCR assay for the quantification of apple proliferation phytoplasmas in plants and insects. Acta Hortic. 657:415-420.

19. Jarausch, W., Saillard, C., Dosba, F., Bové, J. M. 1994. Differentiation of mycoplasmalike organisms (MLOs) in European fruit trees by PCR using specific primers derived from the sequence of a chromosomal fragment of the apple proliferation MLO. Appl. Environ. Microbiol. 60:2916-2923.

20. Krczal, G., Krczal, G., Krczal H., and Kunze, L. 1989. Fieberiella florii (Stal) - a vector of the apple proliferation agent. Acta Hortic. 235:99-104.

21. Kunze, L. 1989. Apple proliferation. Pages 99-113 in: Virus and Viruslike Diseases of Pome Fruits and Simulating Noninfectious Disorders. P. R. Fridlund, ed. Cooperative Extension College of Agriculture and Home Economics, Washington State University, Pullmann.

22. Lauterer, P. 1999. Results of the investigations on Hemiptera in Moravia, made by the Moravian museum (Psylloidea 2). Acta Mus. Morav. Sci. Nat. 84:71-151. 
23. Lorenz, K. H., Schneider, B., Ahrens, U., and Seemüller, E. 1995. Detection of the apple proliferation and pear decline phytoplasmas by PCR amplification of ribosomal and nonribosomal DNA. Phytopathology 85:771-776.

24. Maixner, M., Ahrens, U., and Seemüller, E. 1995. Detection of the German grapevine yellows (Vergilbungskrankheit) MLO in grapevine, alternative hosts and a vector by a specific PCR procedure. Eur. J. Plant Pathol. 101:241-250.

25. Marzachi, C., Milne, R. G., and Bosco, D. 2004. Phytoplasma-plantvector relationship. Pages 211-241 in: Recent Research and Development in Plant Pathology. S. G. Pandalai and A. Gayathri, eds. Research Signpost, Kerala, India.

26. Mattedi, L., Forno, F., Cainelli, C., Grando, M. S., and Jarausch, W. 2008. Research on 'Candidatus Phytoplasma mali' transmission by insect vectors in Trentino. Acta Hortic. 781:369-374.

27. Mayer, C. J., Jarausch, B., Jarausch, W., Vilcinskas, A., and Gross, J. 2009. Cacopsylla melanoneura has no relevance as vector of apple proliferation in Germany. Phytopathology 99:729-738.

28. Mayer, C. J., Vilcinskas, A., and Gross, J. 2008. Pathogen-induced release of plant allomone manipulates vector insect behaviour. J. Chem. Ecol. 34:1518-1522.

29. Mayer, C. J., Vilcinskas, A., and Gross, J. 2008. Phytopathogen lures its insect vector by altering host plant odor. J. Chem. Ecol. 34:1045-1049.

30. Mayer, C. J., Vilcinskas, A., and Gross, J. 2010. Chemically mediated multitrophic interactions in a plant-insect vector-phytoplasma system compared with a partially nonvector species. Agric. For. Entomol. Online publication. doi:10.1111/j:1461-9563.

31. Müther, J., and Vogt, H. 2003. Sampling methods in orchard trials: A comparison between beating and inventory sampling. IOBC/WPRS Bull. 26:67-72.

32. Ossiannilsson, F. 1992. The Psylloidea (Homoptera) of Fennoscania and Denmark. Fauna Entomologica Scandinavica 26. E. J. Brill, Leiden.

33. Pedrazzoli, F., Gualandri, V., Forno, F., Mattedi, L., Malagnini, V., Salvadori, G., and Ioriatti, C. 2007. Acquisition capacities of the overwintering adults of the psyllid vectors of Candidatus Phytoplasma mali. Bull. Insectol. 60:195-196.

34. Rui, D., Ciferri, R., and Refatti, E. 1950. La virosi degli "scopazzi del melo" nel Veronese. Not. Mal. Piante 13:7-11.

35. Schneider, B., Seemüller, E., Smart, C. D., and Kirkpatrick, B. C. 1995. Phylogenetic classification of plant pathogenic mycoplasma-like organism or phytoplasmas. Pages 369-380 in: Molecular and Diagnostic Procedures in Mycoplasmology. S. Razin and J. G. Tully, eds. Academic Press, San Diego, CA.

36. Seemüller, E. 1990. Apple proliferation. Pages 67-68 in: Compendium of Apple and Pear Diseases. A. L. Jones and H. S. Aldwinkle, eds. American Phytopathological Society, St. Paul, MN.

37. Seemüller, E., Kison, H., and Lorenz, K. H. 1998. On the geographic distribution and prevalence of the apple proliferation phytoplasma in lowintensity orchards in Germany. J. Plant Dis. Prot. 105:404-410.

38. Seemüller, E., and Schneider, B. 2004. 'Candidatus Phytoplasma mali', 'Candidatus Phytoplasma pyri' and 'Candidatus Phytoplasma prunorum', the causal agents of apple proliferation, pear decline and European stone fruit yellows, respectively. Int. J. Syst. Evol. Microbiol. 54:1217-1226.

39. Tedeschi, R., and Alma, A. 2006. Fieberiella florii (Homoptera: Auchenorrhyncha) as a vector of 'Candidatus Phytoplasma mali' Plant Dis. 90:284-290.

40. Tedeschi, R., and Alma, A. 2007. 'Candidatus Phytoplasma mali': The current situation of insect vectors in northwestern Italy. Bull. Insectol. 60:187-188.

41. Tedeschi, R., Bosco, D., and Alma, A. 2002. Population dynamics of Cacopsylla melanoneura (Homoptera: Psyllidae), a vector of apple proliferation phytoplasma in Northwestern Italy. J. Econ. Entomol. 95:544-551.

42. Tedeschi, R., Visentin, C., Alma, A., and Bosco, D. 2003. Epidemiology of apple proliferation (AP) in Northwestern Italy: evaluation of the frequency of AP-positive psyllids in naturally infected populations of Cacopsylla melanoneura (Homoptera: Psyllidae). Ann. Appl. Biol. 142:285-290.

43. Thébaud G., Yvon M., Alary R., Sauvion N., and Labonne G., 2009. Efficient transmission of 'Candidatus Phytoplasma prunorum' is delayed by eight months due to a long latency in its host-alternating vector. Phytopathology 99:265-273.

44. Weintraub, P. G., and Beanland, L. 2006. Insect vectors of phytoplasmas. Annu. Rev. Entomol. 51:91-111. 